\title{
PREVALENCE AREAS AND DAMAGE RATE OF CONTARINIA PRUNIFLORUM COUTIN \& RAMBIER (DIPTERA: CECIDOMYIIDAE) IN APRICOT ORCHARDS IN MALATYA AND ELAZIG PROVINCES (TURKEY)
}

\author{
Talip Yiğit ${ }^{* 1}$ (D), Hasan Tunaz ${ }^{2}$ iD \\ ${ }^{1}$ Apricot Research Institute, Malatya, Turkey \\ ${ }^{2}$ Department of Plant Protection, Faculty of Agriculture, Kahramanmaras Sutcu Imam University, Kahramanmaras, Turkey
}

\section{Abstract}

Original scientific paper

Apricot flower midge (Contarinia pruniflorum) emerged in February-March and lay eggs on the flower buds of the apricot trees. The larvae hatching feeds through the bud wall and flower genital organs. The damaged flower does not turn into fruit. It is a pest that directly affects the yield. This study was carried out in Malatya and Elazig provinces (Turkey) in 2017-2018. Prevalence areas in apricot orchards and the damage rate were determined. The highest infestation rate of the pest is in Kale and Battalgazi districts of Malatya and Baskil district of Elazı ̆ with $100 \%$, then, Yeşilyurt 95\%,Yazıhan 90\%,Akçadağ 76\%, Darende 75\%, Kuluncak 50\%, Arguvan 50\% and Doğanşehir 12.5\% followed by infestation rates. No pests were found in the orchards which were controlled in Hekimhan district of Malatya and Elbistan district of Kahramanmaraş. Although the damage rate varies according to years, it was determined that the flower damage rate was $0.7 \%$ and the fruit set rate was $10.6 \%$ in orchard in Kale where the pest control is done, while the damage rate was $11.8 \%$ and the fruit set rate was $2.9 \%$ in the orchard without pest control in 2017. In 2018, when compared with orchards with or without pest control, while there was damage in the number of flowers, but there was no change in the amount of fruit.

Keywords: Apricot, Contarinia pruniflorum, damage rate, Elazığ, Malatya.

\section{Introduction}

Apricot flower midge (Contarinia pruniflorum Coutin \& Rambier Diptera: Cecidomyiidae) was firstly identified in Prunus species [1]. Then, it was detected in culture Prunus species in Czechoslovakia, Italy, Greece, and Turkey. Some studies have been done on this pest by researchers such as determination and pest control [2-6]. First time in Turkey, it was determined that apricot damage given by this pest in Malatya province [7,20,21]. C. pruniflorum, a new pest of apricot, was first identified morphologically by molecular characterization using the COI gene sequence [21].

Adults of the pest lay eggs on the flower buds of the tree, the larvae hatching feeds through the bud wall and flower genital organs. The damaged flower does not turn into fruit. Apricot is an important source of economic income for Malatya and its districts. Half of the apricot trees, approximately 16 million, in Turkey are planted in Malatya [8]. This number is increasing every year. Turkey which produces $60 \%$ of the world's dried apricot is also the dominant country in apricot export [19]. Approximately $85 \%$ of dried apricots in Turkey are produced in Malatya province [9].

Many pest species are threatening this source of income such as Apricot flower midge. Especially for climatic reasons, the pest population has increased for a few years and caused serious damage especially in the apricot orchards of Malatya province. Knowling of its prevalence area and damage rate is necessary for pest control.

The study was conducted to determine the prevalence areas in apricot orchards in Malatya province and its vicinity to the pest control correctly. Also, the damage rate in Kale district of Malatya province in Turkey was determined.

\section{Material and Method}

The material of the study was apricot flower midge, apricot trees and the results of previous studies.

\subsection{Determination of Prevalence Areas of Contarinia Pruniflorum}

The study was conducted in Kale, Battalgazi, Yeşilyurt, Yazihan, Hekimhan, Akçadağ, Arguvan, Doğanşehir, Kuluncak districts of Malatya province with Baskil district of Elazığ in 2017 and, in Darende district of Malatya and Elbistan district of Kahramanmaraş province in 2018. The study area comprises approximately $53 \%$ of the Turkey apricot trees [10]. Orchards were controlled in these areas in the apricot 
flowering period (February, March, April). Survey studies were conducted by making systematic samplings based on $0.01 \%$ of the total number of trees [11]. While representing the number of trees to be controlled in the selected orchards, the number of trees controlled in each orchard is limited to a maximum of 6 trees for sampling in more orchards. The number of trees checked is given in Table 1. During the survey, the trees were examined by the eye. Each tree was examined for at least 3 minutes and the inside of the unbossed buds was examined. When the pests were detected in the controls, that tree was admitted as contaminated.

Plant parts contaminated with pests were collected and put on paper bags and brought to the laboratory and necessary counts were made. The prevalence rate was determined by comparing the contaminated trees to the total examined number of trees.

\subsection{Determination of Damage Rate}

The studies; It was carried out in an apricot orchard in Kale district of Malatya, where the pest population is dense. Insecticide ( $25 \mathrm{~g}$ deltamethrin, $30 \mathrm{ml}$ dose in 100 liters of water) was applied to the selected four trees during the period of laying eggs (23.02.2017 for 2017 and 11.02.2018 for 2018) of the pest. No insecticide was applied to 4 other trees. Then, in the flowering period, 250's flowers were counted from 1.5-2 m height, 4 sides of each tree and, damaged flowers and the fruit set rate were counted. The data were analyzed with the SPSS 16.0 statistical program. The studies were conducted in 2017 and 2018 for 2 years.

\section{Results and Discussion}

\subsection{Prevalence Areas of Contarinia Pruniflorum}

Table 1 shows the number of controlled trees and infestation rates in the districts.

When Table 1 is examined, the highest infestation rate of the pest is in Kale and Battalgazi districts of Malatya and Baskil district of Elazı ̆ with $100 \%$, then, Yeşilyurt 95\%, Yazihan 90\%, Akçadağ 76\%, Darende 75\%, Kuluncak 50\%, Arguvan 50\%, Dogansehir $12.5 \%$ followed by infestation rates. No pests were found in the orchards controlled in Hekimhan district of Malatya and Elbistan district of Kahramanmaraş.

Table 1. The number of apricot trees in the study area and trees controlled

\begin{tabular}{|c|c|c|c|c|c|}
\hline Provinces & Districts & $\begin{array}{c}\text { Total number of } \\
\text { trees (Piece) }\end{array}$ & $\begin{array}{c}\text { Controlled tree } \\
(\text { Piece })\end{array}$ & $\begin{array}{c}\text { Infested trees } \\
(\text { Piece })\end{array}$ & $\begin{array}{c}\text { Infestation rate } \\
(\%)\end{array}$ \\
\hline \multirow{10}{*}{ Malatya } & Battalgazi & 1210000 & 120 & 120 & 100 \\
\hline & Yeşilyurt & 1115000 & 120 & 114 & 95 \\
\hline & Akçadağ & 1416000 & 150 & 114 & 76 \\
\hline & Arguvan & 168400 & 24 & 12 & 50 \\
\hline & Darende & 1233850 & 120 & 90 & 75 \\
\hline & Doğanşehir & 465700 & 48 & 6 & 12.5 \\
\hline & Hekimhan & 815000 & 84 & 0 & 0 \\
\hline & Kale & 184540 & 36 & 36 & 100 \\
\hline & Kuluncak & 378500 & 36 & 18 & 50 \\
\hline & Yazıhan & 651500 & 60 & 54 & 90 \\
\hline Elazı̆̆ & Baskil & 768060 & 84 & 84 & 100 \\
\hline Kahramanmaraş & Elbistan & 1114000 & 132 & 0 & 0 \\
\hline
\end{tabular}

C. pruniflorum was firstly identified in wild Prunus species such as Prunus sipinosa and Prunus mahaleb [1]. However, nowadays the damage to species such as apricot and plum has increased. Although the wild Prunus species are their main hosts, the pest has started to damage Prunus species such as apricot and plum grown commercially and having similar phenological periods with the increase of pest population. [12] stated that the life cycle of the pest was very closely related to the phenology of the host plant and the increase in the density of this insect in apricot trees might be related to the synchronization of the phenology of apricot with the phenology of wild Prunus species. They also stated that this may be the reason why $C$. pruniflorum migrated from the main host plants to apricot.

The pest has been so far determined in France-DromeHeraulth-Normandy regions [1,12,13], Italy- Bologna [2], Czechia [14], Belgium [4], Greece- Corinth [15] and Turkey-Malatya [7,20]. When we consider the regions where the pest is generally seen in the Mediterranean countries, and the pest prefers apricot trees or the damage in apricot is more apparent.

\subsection{Damage Rate}

To determine the damage rate, counts were made in the parcels pesticide applied and pesticide-free, and given in Table 2- 3. Statistical evaluation of the data is given in Table 4-5. In 2017, there was a statistical difference between pesticide applied and pesticide-free applications. In 2018, although there was a statistically significant difference in the number of damaged flowers and the damage rate of flowers, there was no difference in the fruit set rate.

When Table 2 is examined, it is seen that the average flower damage rate of the pesticide-free orchard is $11.8 \%$ and the fruit set rate is $2.9 \%$ in 2017 , while the flower damage rate in the pesticide applied orchard is $0.7 \%$ and the fruit set rate is $10.6 \%$. When Table 3 is examined, it is seen that the average flower damage rate in the pesticidefree orchard is $3.8 \%$ and the fruit set rate is $19.8 \%$, the flower damage rate in the pesticide applied orchard is $0.1 \%$ and the fruit set rate is $20.7 \%$ in 2018 . According to meteorological data in 2018 , the air temperature in the 
first half of February (Table 6) was higher than the seasonal norms, which caused the high insect population. However, high temperatures led to rapid growth in the plant, which caused the flower buds to develop rapidly, thereby shortening the appropriate period for the insect to lay eggs. Although the population is high, it is considered that the damage level in the buds is low due to the short duration of overlap between the oviposition time and the phenological period of the plant. The physiological development of the plant and consequently the suitability of the phenological period affected the insect damage.
[16] reported that the flower damage caused by $C$. pruniflorum in apricot orchards in Greece reached 60$65 \%$. This ratio is very high and can result in a significant decrease in yield.

To determine the effect of the direction in applications; pesticide applied and pesticide-free applications were subjected to the Anova test in SPSS 16.0 statistical program under 4 different groups (east, west, north, and south) and it was found that the directions were not important in both years.

Table 2. Damage Rate of Contarinia pruniflorum (2017)

\begin{tabular}{|c|c|c|c|c|c|c|c|c|c|}
\hline \multirow[t]{2}{*}{ Replications } & \multirow{2}{*}{$\begin{array}{l}\text { Number } \\
\text { of } \\
\text { checked } \\
\text { flowers } \\
\text { (Piece) }\end{array}$} & \multicolumn{2}{|c|}{$\begin{array}{l}\text { Number of damaged } \\
\text { flowers (Piece) }\end{array}$} & \multicolumn{2}{|c|}{$\begin{array}{c}\text { Flower damage rate } \\
(\%)\end{array}$} & \multicolumn{2}{|c|}{ Fruit set (Pieces) } & \multicolumn{2}{|c|}{ Fruit set rate $(\%)$} \\
\hline & & $\begin{array}{c}\text { pesticide } \\
\text { applied }\end{array}$ & $\begin{array}{l}\text { pesticide- } \\
\text { free }\end{array}$ & $\begin{array}{l}\text { pesticide } \\
\text { applied }\end{array}$ & $\begin{array}{l}\text { pesticide- } \\
\text { free }\end{array}$ & $\begin{array}{l}\text { pesticide } \\
\text { applied }\end{array}$ & $\begin{array}{l}\text { pesticide- } \\
\text { free }\end{array}$ & $\begin{array}{l}\text { pesticide } \\
\text { applied }\end{array}$ & $\begin{array}{l}\text { pesticide- } \\
\text { free }\end{array}$ \\
\hline 1. Rep. & 1000 & 6 & 164 & 0.6 & 16.4 & 109 & 42 & 10.9 & 4.2 \\
\hline 2. Rep. & 1000 & 8 & 96 & 0.8 & 9.6 & 40 & 45 & 4 & 4.5 \\
\hline 3. Rep. & 1000 & 8 & 123 & 0.8 & 12.3 & 163 & 18 & 16.3 & 1.8 \\
\hline 4. Rep. & 1000 & 6 & 89 & 0.6 & 8.9 & 112 & 11 & 11.2 & 1.1 \\
\hline Mean & & 7 & 118 & 0.7 & 11.8 & 106 & 29 & 10.6 & 2.9 \\
\hline
\end{tabular}

Table 3. Damage Rate of Contarinia pruniflorum (2018)

\begin{tabular}{|c|c|c|c|c|c|c|c|c|c|}
\hline \multirow[t]{2}{*}{ Replications } & \multirow{2}{*}{$\begin{array}{c}\text { Number } \\
\text { of } \\
\text { checked } \\
\text { flowers } \\
\text { (Piece) }\end{array}$} & \multicolumn{2}{|c|}{$\begin{array}{l}\text { Number of damaged } \\
\text { flowers (Piece) }\end{array}$} & \multicolumn{2}{|c|}{$\begin{array}{c}\text { Flower damage rate } \\
(\%)\end{array}$} & \multicolumn{2}{|c|}{ Fruit set (Pieces) } & \multicolumn{2}{|c|}{ Fruit set rate $(\%)$} \\
\hline & & $\begin{array}{c}\text { pesticide } \\
\text { applied }\end{array}$ & $\begin{array}{l}\text { pesticide- } \\
\text { free }\end{array}$ & $\begin{array}{c}\text { pesticide } \\
\text { applied }\end{array}$ & $\begin{array}{l}\text { pesticide- } \\
\text { free }\end{array}$ & $\begin{array}{c}\text { pesticide } \\
\text { applied }\end{array}$ & $\begin{array}{l}\text { pesticide- } \\
\text { free }\end{array}$ & $\begin{array}{c}\text { pesticide } \\
\text { applied }\end{array}$ & $\begin{array}{l}\text { pesticide- } \\
\text { free }\end{array}$ \\
\hline 1. Rep. & 1000 & 1 & 61 & 0.1 & 6.1 & 189 & 194 & 18.9 & 19.4 \\
\hline 2. Rep. & 1000 & 1 & 34 & 0.1 & 3.4 & 228 & 242 & 22.8 & 24.2 \\
\hline 3. Rep. & 1000 & 0 & 31 & 0 & 3.1 & 160 & 214 & 16.0 & 21.4 \\
\hline 4. Rep. & 1000 & 2 & 29 & 0.2 & 2.9 & 253 & 144 & 25.3 & 14.4 \\
\hline Mean & & 1 & 38.75 & 0.1 & 3.87 & 207.5 & 198.5 & 20.75 & 19.85 \\
\hline
\end{tabular}

Table 4. T-test results between pesticide applied and pesticide-free applications (2017)

\begin{tabular}{llccccc}
\hline & & $\mathrm{N}$ & mean & Standard deviation & $\mathrm{F}$ & Sig.(p) \\
\hline Damaged flower (pieces) & pesticide-free & 16 & 29.5000 & 14.04279 & 15.86 & 0.00 \\
& pesticide applied & 16 & 1.7500 & .77460 & & \\
\hline Flower damage rate (\%) & pesticide-free & 16 & 11.8000 & 5.61712 & 15.86 & 0.00 \\
& pesticide applied & 16 & .7000 & .30984 & & \\
\hline Fruit set (pieces) & pesticide-free & 16 & 7.2500 & 6.07179 & & 0.00 \\
& pesticide applied & 16 & 26.5000 & 19.74842 & 8.83 & \\
\hline Fruit set rate (\%) & pesticide-free & 16 & 2.9000 & 2.42872 & 8.83 & 0.00 \\
& pesticide applied & 16 & 10.6000 & 7.89937 & & \\
\hline
\end{tabular}

Table 5. T-test results between pesticide applied and pesticide-free applications (2018)

\begin{tabular}{|c|c|c|c|c|c|c|}
\hline & & $\mathrm{N}$ & mean & Standard deviation & $\mathrm{F}$ & Sig.(p) \\
\hline \multirow[t]{2}{*}{ Damaged flower (pieces) } & pesticide-free & 16 & 9.6875 & 5.05594 & & \\
\hline & pesticide applied & 16 & 0.2500 & 0.57735 & 11.758 & 0.002 \\
\hline \multirow[t]{2}{*}{ Flower damage rate $(\%)$} & pesticide-free & 16 & 3.8750 & 2.02237 & & \\
\hline & pesticide applied & 16 & 0.1000 & 0.23094 & 11.758 & 0.002 \\
\hline \multirow[t]{2}{*}{ Fruit set (pieces) } & pesticide-free & 16 & 49.6250 & 22.15664 & & \\
\hline & pesticide applied & 16 & 51.8750 & 12.53196 & 7.014 & 0.13 \\
\hline \multirow[t]{2}{*}{ Fruit set $(\%)$} & pesticide-free & 16 & 19.8500 & 8.86266 & & \\
\hline & pesticide applied & 16 & 21.3750 & 5.46303 & 5.327 & 0.28 \\
\hline
\end{tabular}


Table 6. February temperature values in Kale district of Malatya province $\left({ }^{\circ} \mathrm{C}\right)$

\begin{tabular}{|c|c|c|c|c|c|c|}
\hline \multicolumn{4}{|c|}{2017} & \multicolumn{3}{|c|}{2018} \\
\hline Days & $\begin{array}{l}\text { Daily Maximum } \\
\text { Temperature }\end{array}$ & $\begin{array}{l}\text { Daily Minimum } \\
\text { Temperature }\end{array}$ & $\begin{array}{c}\text { Daily Average } \\
\text { Temperature }\end{array}$ & $\begin{array}{l}\text { Daily Maximum } \\
\text { Temperature }\end{array}$ & $\begin{array}{l}\text { Daily Minimum } \\
\text { Temperature }\end{array}$ & $\begin{array}{c}\text { Daily Average } \\
\text { Temperature }\end{array}$ \\
\hline 1 & 2.1 & -5.6 & -2 & 9.8 & 0.4 & 4.7 \\
\hline 2 & 4.9 & -5 & -1.8 & 8.9 & -0.2 & 3.6 \\
\hline 3 & 7.2 & 1 & 4.5 & 9.5 & 3.3 & 7.4 \\
\hline 4 & 6.5 & -3.1 & 1 & 7.7 & 2.3 & 5 \\
\hline 5 & 5.9 & 0 & 2.4 & 10.2 & 3.3 & 6.1 \\
\hline 6 & 8 & 1.4 & 3.8 & 11.6 & 2 & 6 \\
\hline 7 & 8.9 & 0 & 36 & 8.3 & 2.4 & 4.8 \\
\hline 8 & 9.5 & 2.7 & 5.4 & 11.8 & 2.2 & 6.7 \\
\hline 9 & 9.6 & 2.2 & 5.4 & 10.5 & 3.7 & 7.1 \\
\hline 10 & 12 & 3.5 & 7 & 10.1 & 2.4 & 6.2 \\
\hline 11 & 11.1 & 0.8 & 5.7 & 15.8 & 4.8 & 9.1 \\
\hline 12 & 8 & 0.2 & 3.8 & 14.7 & 7.3 & 11.3 \\
\hline 13 & 5.8 & -2.6 & 1.3 & 13.2 & 6 & 9.4 \\
\hline 14 & 4 & -4.6 & 8.6 & 11.7 & 1.8 & 7.5 \\
\hline 15 & 2.9 & -3.5 & 4.2 & 14.1 & 7.2 & $\begin{array}{l}10.9 \\
\end{array}$ \\
\hline 16 & 4.4 & -3.6 & -0.1 & 14.8 & 5.2 & 9.6 \\
\hline 17 & 3.8 & -4.7 & -1 & 12.2 & 7.3 & 9.9 \\
\hline 18 & 5.9 & -5.4 & -0.6 & 7.5 & 4.8 & 6.3 \\
\hline 19 & 8.5 & -3.2 & 1.8 & 11.9 & 1.7 & 6.8 \\
\hline 20 & 9 & -2.2 & 2.8 & 12.4 & 3.8 & 7.6 \\
\hline 21 & 11.3 & -1.5 & 4 & 9.3 & 6.8 & 8.3 \\
\hline 22 & 14.6 & 1.1 & 6.5 & 10.4 & 6.3 & 7.9 \\
\hline 23 & 12.8 & 4.5 & 8.2 & 12.6 & 3.5 & 7.3 \\
\hline 24 & 13.4 & 0.9 & 6.6 & 13.6 & 4.1 & 8.4 \\
\hline 25 & 15.7 & 3.3 & 9.3 & 10.2 & 6.4 & 8.4 \\
\hline 26 & 14 & 3 & 8.4 & 9.2 & 2.5 & 5.5 \\
\hline 27 & 16.1 & 4 & 9.6 & 10.5 & 7.2 & 8.9 \\
\hline 28 & 16.7 & 4.7 & 10.2 & 14.3 & 3.2 & 8.4 \\
\hline
\end{tabular}

When the damage type of the insect is examined; larvae hatching progresses in the flower petals and settles into the bud. There, it begins to eat the bud wall and the flower does not bloom. Therefore, flowers do not turn into fruit and cause damage that affects the amount of product. Damaged buds are seen on the tree even after the flower petals are completely shed at the end of flowering (Fig. 1).

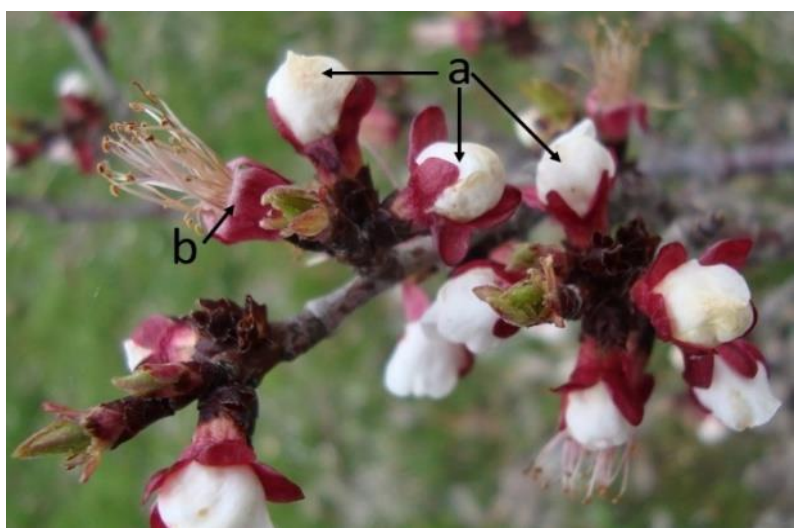

Figure 1. Damage type a- Not bloomed flower with C. pruniflorum, b-Healthy flowers with petals shed at the end of the flowering period

When the population was dense, the harmony between the oviposition time and the phenology of the plant caused harm to both flower and fruit set. [15] stated that the pest was firstly detected in Emilia Romagna, Italy in 1996, although the presence of the pest was very limited at the beginning in apricot, it had a serious effect on apricot blossoms in recent years and the pest symptoms increased especially with late spring frosts.

In the study, it was determined that the insecticide with the active ingredient deltamethrin was successful in the pest control when the pest started to lay eggs. However, the pest control should be decided by monitoring the biological periods of the insect and temperature data, and chemical control should not be made unless necessary. Alternative pest control methods should be developed due to adverse effects of chemicals on the environment, human health, residues in plants, increasing chemical resistance in insects and the pest control in organic orchards where the use of the chemical is restricted. In chemical control studies against to the adult stage, [2] found that microencapsulated fenitrothion treatments were significantly more effective than phosalone and acephate applications in control studies against pest in Bologna Imola, Italy. [12] stated that the reduction of winter oil applications in orchards is beneficial for the pest, however, applications such as an oleoparathion Parathion-ethyl between bud swelling period and red bud period will reduce this damage to a large extent. They stated that it is possible to abolish the use of oleoparathion-based chemicals in Europe by legal regulations and therefore, alternative solutions should be found to eliminate the infestation. On the other hand, they stated that the problem is still not solved in organic orchards and, it is the most important problem in apricot orchards in Drome and should be monitored. [15] stated that the pest control in apricot should be done against adults in Emilia Romagna, Italy in 1996. In the study it is stated that the severity of the damage was due to the harmony between the flight period of the insect and the pink bud period of the apricot, the adults were affected by strong rains, strong winds and severe temperature drops and the side effects of insecticides to the environment and other beneficial insects should be taken into consideration 
when chemical control is made against the pest. [17] reported that apricot flowers, which were attacked by the pest, did not open and hung on the branch, became swollen and blackish. They reported that a pre-flowering pest control against Brachycaudus persicae and Hyalopterus pruni was effective against $C$. pruniflorum using neonicotinoid group chemicals (acetamiprid, clothianidin, imidacloprid, nitenpyram, nithiazine, thiacloprid, and thiamethoxam). Ondet (2004), in the study conducted in GRAB (Groupe de Recherche en Agriculture Biologique) in 2002, it was determined that Quassia amara L. against C. prunuflorum was statistically different from the control application and 60\% more effective. [18] in their study, a ground application with $Q$. amara L. applied to remove the newly emerging adults. According to the results of the flower counting, the application with Quassia did not have a significant difference compared to the control, and so the application of Quassia at ground level was not effective.

As a result; the pest is gradually increasing its prevalence areas over the world. It has been a pest that has a direct effect on the yield, especially in apricot areas, until recently it has not been detected. It is necessary to the pest control if the population is high by determining the emergence time of the pest. Especially in the low population, chemical control should be avoided. It is important to investigate alternative control methods for chemical control such as bioinsecticide use, cultural and biotechnical methods. Sudden temperature drops occurring at the oviposition time, adverse climatic conditions such as precipitation and strong winds, as well as sudden high temperatures that cause rapid progression of plant phenology, have reduced the oviposition of the pest. In such cases, the negative effect of the pest on the fruit set decreases. However, the damage of this insect is more distinct in the years when direct damage occurs in flowers and fruits due to late spring frosts.

\section{Acknowledgements}

We are grateful to the Republic of Turkey Ministry of Agriculture and Forestry General Directorate of Agricultural Research and Policies which provides financial support to our study. Grant number TAGEM/BSAD/16/1/01/01. The authors declare no conflict of interest and ethics committee approval.

\section{References}

[1] Rambier, A. M., \& Coutin, R. (1955). Description d'une nouvelle Cécidomyie sur les fleurs des Prunus: Contarinia pruniflorum $\mathrm{n}$. $\mathrm{sp}$. et ses principaux caractères biologiques [Dipt. Itoniidae]. Bulletin de la Société entomologique de France, 60(7), 104-110.

[2] Pollini, A. (1996). Contarinia pruniflorum un nuovo parassita del'albicocco. Informatore Agrario, 52(39), 71-73.

[3] Ondet, S.J. (2004). Saint-Pierre-des-Corps, A. Journées Techniques Fruits et Légumes Biologiques pp. 39-44. Retrieved October 12, 2019, from http://itab.asso.fr/downloads/actes/actes_jt_fl_2004_tours. pdf.

[4] Roskam, J. C., \& Carbonnelle, S. (2015). Annotated checklist of the gall midges from the Netherlands, Belgium and Luxembourg (Diptera: Cecidomyiidae). Nederlandse faunistische mededelingen, 44, 47-167.
[5] Gagné, R.J., \& Jaschhof, M. (2014). A Catalog of the Cecidomyiidae (Diptera) of the World. Digital version 2, $\mathrm{p}$. 493. Retrieved October 12, 2019, from https://www.ars.usda.gov/ARSUserFiles/80420580/Gagne _2014_World_Cecidomyiidae_Catalog_3rd_Edition.pdf.

[6] Gagné, R.J. \& Jaschhof, M. (2017). A Catalog of the Cecidomyiidae (Diptera) of the World. Digital, p. 762. Retrieved October 12, 2019, from https://www.ars.usda.gov/ARSUserFiles/80420580/Gagne 2017_World_Cat_4th_ed.pdf.

[7] Doğanlar, M., Yiğit, T., Aslan, A., \& Karakaş, H. B. (2014). First record of the apricot flower midge, Contarina pruniflorum Coutin \& Rambier (Diptera: Cecidomyiidae) in Malatya province, Turkey. Munis Entomology \& Zoology, 9(2), 765-769.

[8] TÜİK. (2020)a. Turkish Statistical Institute. Retrieved November $\quad 07, \quad 2021 \quad$ from https://biruni.tuik.gov.tr/medas/?kn=92\&locale=tr.

[9] Gündüz, O., Aslan, A., Ceyhan, V., \& Bayramoğlu, Z. (2021). Measuring the metafrontier efficiencies and technology gaps of dried apricot farms in different agroecological zones.

[10] TÜİK. (2020)b. Turkish Statistical Institute. Retrieved November $\quad 08, \quad 2021 \quad$ from https://biruni.tuik.gov.tr/medas/?kn=92\&locale=tr.

[11] Bora, T., \& Karaca, İ. (1970). Bitki Hastalıkları Surveyi. Kültür Bitkilerinde Hastalı̆̆ın ve Zararın Ölçülmesi, Ege Üniversitesi Ziraat Fakültesi Yardımcı Ders Kitabı, Yayın, (167).

[12] Pierre, E., \& Chauvin-Buthaud, B. (2001). A new pest in the south of France. A midge which gives cause for concern on apricot blossom [Contarinia pruniflorum]. Phytoma. La Défense des Végétaux (France).

[13] Skuhravá, M. (2005). Gall midges of France (Diptera: Cecidomyiidae). Mem. Soc. Linn. Bordeaux, 5, 1-210.

[14] Gagné, R. J. (2010). Update for a catalog of the Cecidomyiidae (Diptera) of the world. Digital version 1. $\mathrm{p}$. 544. Retrieved October 12, 2019 from http://www.ars.usda.gov/SP2UserFiles/Place/12754100/Ga gne_2010_World_Catalog_Cecidomyiidae.pdf.

[15] Tommasini, M. G. (2006). Recenti problematiche fitosanitarie dell'albicocco. Frutticoltura, 9: 68.

[16] Tsagarakis, A.E., \& Mitsopoulus, D. I. (2007). First record of the apricot flower midge Contarinia pruniflorum Coutin \& Rambier (Diptera: Cecidomyiidae) in Greece. 12th National Entomological Congress of Greece, 230 p.

[17] Bugiani, R., \& Bariselli . M. (2008). Albicocco, i disciplinari anticipano la revisione. Terra e Vita, Speciale Difesa Frutteto p 62-63. Retrieved October 10, 2019 from https://agricommerciogardencenter.edagricole.it/agri24/im g/TerraVita102008_SpecialeDifesaFrutteto5.pdf.

[18] Gomez, C., Chauvin-Buthaud, B., \& Stevenin, S. (2006). Lutte contre la Cecidomyie Contarinia pruniflorum en verger d'abricotiers. Arboriculture 2006 A06RA/02. Retrieved October 12, 2019 from http://www.grab.fr/cd2006/Fiche\%20ArboRA\%202\%20ce cidomyie\%202006.pdf.

[19] INC. (2019). Statistical Yearbooks of The International Nut and Dried Fruit Council, Retrieved December 24, 2019 from https://www.nutfruit.org/industry/technicalresources?category=statistical-yearbooks.

[20] Kaplan, M. (2014). A New Pest: Contarinia pruniflorum Coutin \& Rambier (Diptera: Cecidomyiidae) on apricot (Prunus armeniaca) in Malatya province, Turkey. Munis Entomology \& Zoology, 9 (2), s. 947-949.

[21] Kaplan, M. \& İnal, B. (2021). Kaplan, M., \& İnal, B. (2021). Molecular and Morphological Identification of Contarinia pruniflorum Coutin \& Rambier (Diptera: Cecidomyiidae) Which is a Harmful Pest in Apricot Orchards in Turkey. Erwerbs-Obstbau, 1-5. 